\title{
Changes in gene expression of histone modification enzymes in rat granulosa cells undergoing luteinization during ovulation
}

Ryo Maekawa, Lifa Lee, Maki Okada, Hiromi Asada, Masahiro Shinagawa, Isao Tamura, Shun Sato, Hiroshi Tamura and Norihiro Sugino*

\begin{abstract}
Background: The ovulatory LH surge rapidly alters the expression of steroidogenesis-related genes such as steroidogenic acute regulatory protein (StAR) in granulosa cells (GCs) undergoing luteinization. We recently reported that histone modifications contribute to these changes. Histone modifications are regulated by a variety of histone modification enzymes. This study investigated the changes in gene expression of histone modification enzymes in rat GCs undergoing luteinization after the induction of ovulation. The extracellular regulated kinase (ERK)-1/2 is a mediator in the intracellular signaling pathway stimulated by the ovulatory LH surge and regulates the expression of a number of genes in GCs. We further investigated whether ERK-1/2 is involved in the regulation of the histone modification at the StAR promoter region in GCs undergoing luteinization.
\end{abstract}

Results: GCs were obtained from rats treated with equine chorionic gonadotropin (CG) before ( $0 \mathrm{~h}$ ) and after human (h) CG injection. The expressions of 84 genes regulating histone modifications or DNA methylation were measured using a PCR array. Five genes (HDAC4, HDAC10, EZH2, SETDB2, and CIITA) were identified as histone acetylation- or histone methylation-related genes, and were significantly altered after hCG injection. None of the genes were related to DNA methylation. mRNA levels of EZH2, SETDB2, HDAC4, and HDAC10 decreased and CIITA mRNA levels increased 4 or $12 \mathrm{~h}$ after $\mathrm{hCG}$ injection.

GCs isolated after eCG injection were incubated with hCG for $4 \mathrm{~h}$ to induce luteinization. StAR mRNA levels were significantly increased by hCG accompanied by the increase in H3K4me3 of the StAR promoter region. StAR mRNA expression was inhibited by the ERK inhibitor with the significant decrease of H3K4me3. These results suggest that hCG increases StAR gene expression through the ERK-1/2-mediated signaling which is also associated with histone modification of the promoter region.

Conclusions: Gene expressions of histone modification enzymes change in GCs undergoing luteinization after ovulation induction. This change may play important roles in regulating the expression of various genes during the early stage of luteinization, which may be critical for the subsequent corpus luteum formation.

Keywords: Histone modification, Granulosa cells, Ovulation, Luteinization

\footnotetext{
* Correspondence: sugino@yamaguchi-u.ac.jp

Department of Obstetrics and Gynecology, Yamaguchi University Graduate

School of Medicine, Minamikogushi 1-1-1, Ube 755-8505, Japan
} 


\section{Background}

The ovulatory LH surge alters the expression of various genes, which are essential for ovulation, in granulosa cells undergoing luteinization [1]. Among the genes involved in steroidogenesis, the expression of steroidogenic acute regulatory $(S t A R)$ protein, a rate-limiting enzyme for progesterone synthesis, is rapidly induced after the LH surge [2] while the expression of aromatase (Cyp19a1), a key enzyme for estrogen synthesis, is rapidly suppressed [3]. This functional change of steroidogenesis, in which there is a rapid shift from estrogen synthesis to progesterone synthesis, plays a crucial role in follicle rupture and the following corpus luteum formation $[4,5]$.

In recent years, epigenetic mechanisms such as DNA methylation and histone modifications have been shown to be involved in the regulation of gene expression [6-9]. DNA methylation occurs at cytosines within CpG dinucleotides through DNA methyltransferases (DNMT), which can silence gene expression by altering chromatin structure and preventing the binding of transcription factors [10-13]. Histone modifications also affect chromatin structure, which is critical for the interaction of transcriptional factors with response elements in the promoters [10, 14-16]. Histone modifications such as acetylation of histone $\mathrm{H} 3$ and histone $\mathrm{H} 4$ or trimethylation of the site of lysine 4 on histone $\mathrm{H} 3$ (H3K4me3) activate transcription by loosening the chromatin structure and allowing the recruitment of transcriptional factors to their response elements [17-19]. On the other hand, histone modifications such as trimethylation of the site of lysines 9 and 27 on histone $\mathrm{H} 3$ (H3K9me and H3K27me3) inactivate transcription by condensing the chromatin $[20,21]$.

Histone modifications have been reported to regulate the gene expression of StAR, steroidogenesis-related enzymes, and LH receptor in the ovary [22-24]. We recently reported that histone modifications and chromatin remodeling contribute to the rapid induction of the StAR gene and the rapid suppression of the Cyp19a1 gene in granulosa cells undergoing luteinization during ovulation in rats [25]. Levels of histone $\mathrm{H} 4$ acetylation and $\mathrm{H} 3 \mathrm{~K} 4 \mathrm{me} 3$ increased whereas H3K9me3 and H3K27me3 decreased in the StAR promoter after ovulation induction [25]. On the other hand, the levels of histone $\mathrm{H} 3 / \mathrm{H} 4$ acetylation and $\mathrm{H} 3 \mathrm{~K} 4 \mathrm{me} 3$ decreased, and the level of H3K 27 me 3 increased in the cyp19a1 promoter after ovulation induction [25]. Histone modifications are regulated by a variety of histone modification enzymes. Recently, CREB-binding protein $(\mathrm{CBP}) / \mathrm{p} 300$ was shown to regulate the histone acetylation in the promoters of the LH-induced target genes as a histone acetyltransferase in mouse granulosa cells undergoing luteinization after the ovulatory LH surge [26]. However, little information is available on how and which histone modification enzymes change in granulosa cells undergoing luteinization.

The extracellular regulated kinase (ERK)-1/2 is a mediator in the intracellular signaling pathway stimulated by the ovulatory LH surge and regulates the expression of a number of genes including StAR and cyp19a1 in granulosa cells [27]. Recent studies have shown that LH surgerelated signaling pathways regulate the expression of some histone modification enzymes. CBP/p300, a histone acetyltransferase, acts downstream of the ERK-1/2 signal activated by the ovulatory $\mathrm{LH}$ surge in mouse granulosa cells [26]. Two genes (NCOA7 and HP1BP3), which are related to histone modifications or chromatin remodeling, also act downstream of the ERK-1/2 signal and are involved in luteinization of granulosa cells after ovulation induction [27]. These findings led us to investigate that ERK-1/2 is involved in regulating the gene expression through histone modifications in granulosa cells undergoing luteinization after the ovulatory LH surge.

In this study, we first investigated the changes in gene expression of histone modification enzymes in rat granulosa cells undergoing luteinization after ovulation induction. Furthermore, we investigated whether ERK-1/2 is involved in the regulation of the histone modification at the StAR promoter region and its mRNA expression in granulosa cells undergoing luteinization.

\section{Methods}

The present study was reviewed and approved by the Committee for the Ethics on Animal Experiment in Yamaguchi University Graduate School of Medicine.

\section{Animal models}

Female Sprague-Dawley rats (Japan SLC, Hamamatsu, Japan) in 21-24 days old were injected subcutaneously with 15 IU of equine chorionic gonadotropin (eCG) (Sigma, St. Louis, MO, USA) to stimulate follicular growth. After $48 \mathrm{~h}$, the rats were injected subcutaneously with 15 IU of human chorionic gonadotropin (hCG) (Sigma) to induce ovulation and luteinization. The ovaries were dissected before hCG (0 h), 4 and $12 \mathrm{~h}$ after hCG injection. Then, follicles were punctured using 27 G needles, and granulosa cells were isolated. The cells were centrifuged at $800 \mathrm{x}$ g, pelleted, and washed in cold PBS twice. Total RNA was isolated from the cells with Isogen (Wako Pure Chemical Industries Ltd., Osaka) and purified by RNeasy Mini (QIAGEN, Chatsworth, CA). Three to five rats in each time point were used for RT2 profiler PCR array or real-time reverse transcription (RT)-PCR described below.

\section{Collection and culture of granulosa cells}

Culture of granulosa cells was performed as reported previously [28]. Immature (3 weeks) ICR mice (Japan 
SLC Inc.) received a subcutaneous injection of 20 units of eCG to stimulate the development of multiple follicles. Mice were laparotomized under deep ether anesthesia $48 \mathrm{~h}$ after the eCG injection; the ovaries were quickly removed for the following experiments, and the mice were euthanized by exsanguinations. The ovaries were transferred to alpha Modified Eagle Minimum Essential Medium supplemented with penicillin-streptomycin (Invitrogen, Carlsbad, CA, USA). Granulosa cells were collected by puncturing mature preovulatory follicles using a $27 \mathrm{G}$ needle under a dissecting microscope. The cells were centrifuged at $800 \mathrm{x}$ g, washed in PBS twice, and used for cell culture. The cells (at a density of $2.5 \times 10^{4}$ cells/well in $100 \mu \mathrm{l}$ of medium) were incubated with 50 units of hCG for $4 \mathrm{~h}$ to induce luteinization. In this study, high dose of hCG was used to significantly stimulate $S t A R$ gene expression. In addition, to investigate the involvement of the ERK-1/2 signal in the StAR expression, cells were incubated with the inhibitor of ERK-1/2 (U0126, $10 \mu \mathrm{M}$; Cell Signaling Technologies, Danvers, MA, USA) for $2 \mathrm{~h}$ prior to hCG stimulation. After incubation, the cells were used for evaluation of StAR mRNA expression and H3K4me3 status of the StAR promoter region.

\section{Real-time PCR array}

RT of RNA into cDNA was performed using the $\mathrm{RT}^{2}$ First Strand Kit (QIAGEN) in accordance with the instruction manual. In this study, the $\mathrm{RT}^{2}$ Profiler $^{\text {TM }}$ PCR Array, 'Human Epigenetic Chromatin Modification Enzymes' (QIAGEN) covering 84 genes that are related to histone modifications and DNA methylation, was used as we previously reported [29]. Real-time PCR was performed using the $\mathrm{RT}^{2}$ SYBR Green Master Mix (QIAGEN) according to the manufacturer's protocol under the following cycler conditions: $95^{\circ} \mathrm{C}$ : $10 \mathrm{~min} ; 40$ cycles $\left(95^{\circ} \mathrm{C}\right.$ : $15 \mathrm{~s}$; $60{ }^{\circ} \mathrm{C}$ : 60s) using the Applied Biosystems 7700 Real-time PCR cycler (Applied Biosystems, Darmstadt, Germany). The relative quantity of cDNA was calculated with the $\Delta \Delta C_{t}$ method using five normalization genes: $\beta$-2microglobulin, hypoxanthine phosphoribosyltransferase 1 , ribosomal protein L13a, glyceraldehydes-3-phosphate dehydrogenase and $\beta$ actin. A significant change in gene expression among the times examined was defined as at least a 2-fold up- or down-regulation of genes with $p<0.01$.

\section{Real-time RT-PCR}

Total RNA was isolated from cells with Isogen (Wako Pure Chemical Industries Ltd., Osaka, Japan), and realtime RT-PCR was performed as we reported previously [25], using LightCycler with Premix-Ex-Taq (Takara, Ohtsu, Japan) and sequence-specific primer sets of enhancer of zeste homolog 2 (EZH2), SET domain- bifurcated 2 (SETDB2), histone deacetylase 4 (HDAC4), HDAC10, class II, major histocompatibility complex, transactivator (CIITA), nuclear receptor coactivator 7 (NCOA7), heterochromatin protein 1-binding protein 3 (HP1BP3), StAR and GAPDH (Table 1). The thermocycling program was 40 cycles of $95 \mathrm{C}$ for $5 \mathrm{~s}$ and $60 \mathrm{C}$ for $20 \mathrm{~s}$ with an initial cycle of $95 \mathrm{C}$ for $10 \mathrm{~s}$. RT-PCR amplification was also performed using a programmed temperature control system (PC808, ASTEC, Fukuoka, Japan). PCR products were separated on $2 \%$ agarose-gel.

\section{Chromatin immunoprecipitation assay (ChIP assay)}

ChIP assays were performed according to the protocol for the ChIP assay kit (Upstate Biotechnology, Lake Placid, NY, USA) as reported previously [25] with some modifications. Cells were cross-linked by addition of formaldehyde into the medium at a final concentration of $1 \%$ and incubated for $10 \mathrm{~min}$ at $37{ }^{\circ} \mathrm{C}$. Cross-linking was terminated by addition of glycine $(0.125 \mathrm{M}$, final concentration). Cells were washed with ice-cold PBS containing protease inhibitors (Sigma) and resuspended in ChIP lysis buffer (1 \% SDS, 10 mM EDTA, 50 mM Tris$\mathrm{HCl}, \mathrm{pH}$ 8.0, with protease inhibitors). The lysates were sonicated using a Bioruptor ultrasonicator (Cosmo-bio, Tokyo, Japan). After preclearing the lysate with salmon sperm DNA-protein A at $4{ }^{\circ} \mathrm{C}$ for $4 \mathrm{~h}$, lysates were diluted with ChIP dilution buffer (0.01\% SDS, $1.1 \%$ Triton $\mathrm{X}-100,1.2 \mathrm{mM}$ EDTA, $16.7 \mathrm{mM}$ Tris-HCl, pH 8.0, $167 \mathrm{mM} \mathrm{NaCl}$, with protease inhibitors) and $5 \%$ of the supernatant were kept as input controls (INPUT). Dynabeads Protein A (Invitrogen) were incubated with antibodies for EZH2 (Santa Cruz Biotechnology, Inc., Santa Cruz, CA), H3K4me3 (generous gift from Dr. Kimura, Osaka University, Osaka, Japan) and normal rabbit IgG (Invitrogen) $4{ }^{\circ} \mathrm{C}$ overnight. The precleared chromatin was incubated with antibody-bound Dynabeads for $6 \mathrm{~h}$ at $4{ }^{\circ} \mathrm{C}$. Immune complexes were collected and washed once for $5 \mathrm{~min}$ on a rotating platform with $1 \mathrm{ml}$ each of the following buffers in sequence: low salt wash buffer $(0.1 \%$ SDS, $1 \%$ Triton X-100, 2 mM EDTA, 20 mM Tris- $\mathrm{HCl}$, $\mathrm{pH}$ 8.0, $150 \mathrm{mM} \mathrm{NaCl}$ ), high salt wash buffer (0.1\% SDS, $1 \%$ Triton X-100, $2 \mathrm{mM}$ EDTA, $20 \mathrm{mM}$ Tris- $\mathrm{HCl}$, pH 8.0, $1500 \mathrm{mM} \mathrm{NaCl}), \mathrm{LiCl}$ wash buffer $(250 \mathrm{mM} \mathrm{LiCl}$, $1 \%$ Nonidet P-40, $1 \%$ sodium deoxycholate, $1 \mathrm{mM}$ EDTA, $10 \mathrm{mM}$ Tris- $\mathrm{HCl}, \mathrm{pH}$ 8.0), and twice with TE (10 mM Tris- $\mathrm{HCl}, \mathrm{pH}$ 8.0, $1 \mathrm{mM}$ EDTA). Immune complexes were eluted with $200 \mu$ l elution buffer (1 \% SDS, 0.1 M NaHCO $3,10 \mathrm{mM}$ DTT). Cross-linking of the immunoprecipitated chromatin complexes (IP) and INPUT were reversed by heating the samples at $65{ }^{\circ} \mathrm{C}$ overnight and subjected to proteinase $\mathrm{K}$ treatment. The DNA fragments were purified using a QIAquick PCR purification kit (QIAGEN) and subjected as a template for PCR amplification. The specific primers were used for 
Table 1 Primers used for real-time RT PCR

\begin{tabular}{|c|c|c|c|}
\hline Gene & & Primer (5' to $\left.3^{\prime}\right)$ & Amplification size (bp) \\
\hline \multirow[t]{2}{*}{$\overline{\mathrm{EZH} 2}$} & Forward & GCTCTITTGTCGACGATGTTT & 63 \\
\hline & Reverse & TTGGGTGTTGCATGAAAGG & \\
\hline \multirow[t]{2}{*}{ SETDB2 } & Forward & GCAACACCAAAAGATGGAAGA & 65 \\
\hline & Reverse & CATCTTGTAGCTCCATCCAGAA & \\
\hline \multirow[t]{2}{*}{ HDAC10 } & Forward & CGATGTGTAGCCCATAGAGGT & 93 \\
\hline & Reverse & CCACAGAATTCTCCCATTGC & \\
\hline \multirow[t]{2}{*}{ HDAC4 } & Forward & CACACCTCTTGGAGGGTACAA & 68 \\
\hline & Reverse & AGCCCATCAGCTGTTITGTC & \\
\hline \multirow[t]{2}{*}{ CIITA } & Forward & TCCTTCCAGCATTCTCTTCC & 65 \\
\hline & Reverse & CCCGATCTTGTTCTCGCTAA & \\
\hline \multirow[t]{2}{*}{ NCOA7 } & Forward & CCACCAAGAGCTGGGAGAT & 76 \\
\hline & Reverse & TCCTCCTCATAGTAGCTGCAAGT & \\
\hline \multirow[t]{2}{*}{ HP1BP3 } & Forward & TGAAGGGGAAGAAGAAAAACC & 93 \\
\hline & Reverse & GGAGCAGGTGGAGTCTCATT & \\
\hline \multirow[t]{2}{*}{ STAR } & Forward & GAAAGCCAGCAGGAGAATGG & 78 \\
\hline & Reverse & CACCTCCAGTCGGAACACCTT & \\
\hline \multirow[t]{2}{*}{ GAPDH } & Forward & CTCATGACCACAGTCCATGC & 155 \\
\hline & Reverse & TTCAGCTCTGGGATGACCTT & \\
\hline
\end{tabular}

ChIP-PCR analysis to amplify the StAR promoter region as reported previously [25]. To determine the relative levels of EZH2 recruitment and H3K4me3 statuses of the StAR promoter region, real-time PCR analysis was performed and the ratio of IP DNA to the INPUT DNA sample (\%INPUT) was calculated as reported previously [25].

\section{Statistical analysis}

In the real-time PCR array, a paired $t$-test $(0 \mathrm{~h}$ vs $4 \mathrm{~h}$ and $0 \mathrm{~h}$ vs $12 \mathrm{~h}$ ) was used to identify statistical differences for each transcript. All statistical analyses were performed using a web-based PCR array data analysis which is provided by the manufacture (Qiagen). Differences were considered significant at $p<0.01$. In the RT-PCR, statistical significance was determined by oneway ANOVA. After ANOVA, the Tukey-Kramer test was applied to analyze differences between groups. In the in vitro study, unpaired $t$ test was applied to analyze differences between two groups. All statistical analyses were performed using SPSS for Windows version 11 (SPSS Inc., Chicago, IL). Differences were considered significant at $p<0.05$.

\section{Results}

Among the 84 genes in the PCR array, three genes were up- or down-regulated by a factor of at least 2-fold between 0 and $4 \mathrm{~h}$; RPS6KA5 was up-regulated and HDAC10 and SETDB2 were down-regulated (Table 2). In addition, two genes (NEK6 and CIITA) were upregulated and eight genes (AURKC, AURKB, HDAC10,
SETDB2, HDAC4, EZH2, PAK1 and CDK2) were downregulated by at least 2 -fold between 0 and $12 \mathrm{~h}$; (Table 3 ). All of these genes were related to histone modifications, but none of them were related to DNA methylation such as DNMT1, DNMT3a, and DNMT3b.

Five (EZH2, SETDB2, HDAC4, HDAC10, and CIITA) of the up- or down-regulated genes were related to histone acetylation or histone methylation. The changes in mRNA levels of the five genes were validated with additional samples ( $n=5$ in each time point) by real-time RT-PCR. EZH2 forms the polycomb-repressive complex 2 with other components and serves as the enzyme that induces H3K27me3 leading to gene silencing [30, 31]. The mRNA expression level of EZH2 significantly decreased between 0 and $12 \mathrm{~h}$ (Fig. 1). SETDB2 has transcriptional repression activities through inducing H3K9me3 [32]. The mRNA expression of SETDB2 significantly decreased at 4 and $12 \mathrm{~h}$ after hCG injection (Fig. 1). HDACs

Table 2 Genes with a 2-fold up- or down-regulation between 0 and $4 \mathrm{~h}$

\begin{tabular}{llll}
\hline Genes & Modifications & Fold & $P$ value \\
\hline Upregulated & & & \\
$\begin{array}{l}\text { RPS6KA5 (Ribosomal protein } \\
\text { S6 kinase, aipha5) }\end{array}$ & Histone Phosphorylation & 3.74 & 0.0042 \\
$\begin{array}{l}\text { Downregulated } \\
\text { HDAC10 (Histone }\end{array}$ & Histone Deacetylases & -2.17 & 0.0054 \\
$\begin{array}{l}\text { deacetylase 10) } \\
\text { SETDB2 (SET domain, } \\
\text { bifurcated 2) }\end{array}$ & Histone & & \\
\hline
\end{tabular}


Table 3 Genes with a 2-fold up- or down-regulation between 0 and $12 \mathrm{~h}$

\begin{tabular}{|c|c|c|c|}
\hline Genes & Modifications & Fold & $P$ value \\
\hline \multicolumn{4}{|l|}{ Upregulated } \\
\hline NEK6 (NIMA (never in mitosis gene a)-related kinase 6) & Histone Phosphorylation & 2.02 & 0.0002 \\
\hline CIITA (Class II, major histocompatibility complex, transactivator) & Histone Acetyltransferases & 2.29 & 0.0085 \\
\hline \multicolumn{4}{|l|}{ Downregulated } \\
\hline AURKC (Aurora kinase C) & Histone Phosphorylation & -3.51 & 0.0008 \\
\hline AURKB (Aurora kinase B) & Histone Phosphorylation & -2.83 & 0.0017 \\
\hline HDAC10 (Histone deacetylase 10) & Histone Deacetylases & -2.65 & 0.0026 \\
\hline SETDB2 (SET domain, bifurcated 2) & Histone Methyltransferases & -3.11 & 0.0030 \\
\hline HDAC4 (Histone deacetylase 4) & Histone Deacetylases & -2.14 & 0.0029 \\
\hline EZH2 (Enhancer of zeste homolog 2 (Drosophila)) & Histone Methyltransferases: & -2.55 & 0.0050 \\
\hline PAK1 (P21 protein (Cdc42/Rac)-activated kinase 1) & Histone Phosphorylation & -4.21 & 0.0044 \\
\hline CDK2 (Cyclin dependent kinase 2) & Histone Phosphorylation & -2.00 & 0.0099 \\
\hline
\end{tabular}

remove acetyl groups from acetylated histones and lead to inactivation of gene expressions [33]. HDAC4 and HDAC10 belong to class II histone deacetylases and have tissue-specific expressions [34]. HDAC4 is most strongly expressed in heart, skeletal muscle and brain while HDAC10 is expressed in liver, spleen and kidney [34]. The mRNA levels of HDAC4 and HDAC10 significantly decreased at $12 \mathrm{~h}$, and at 4 and $12 \mathrm{~h}$ after hCG injection, respectively (Fig. 1). CIITA is a master regulator of major histocompatibility complex (MHC) class II genes and works as a histone acetyltransferase [35]. The mRNA expression of CIITA significantly increased at $12 \mathrm{~h}$ (Fig. 1).

Two genes (NCOA7 and HP1BP3) are related to histone modifications or chromatin remodeling, and are involved in luteinization of granulosa cells after ovulation induction by working downstream of the ERK-1/2 signal [27]. NCOA7 is an estrogen receptor coactivator that possesses intrinsic histone acetyltransferase activities [36, 37]. HP1BP3 is a component of heterochromatin that maintains heterochromatin integrity $[38,39]$.

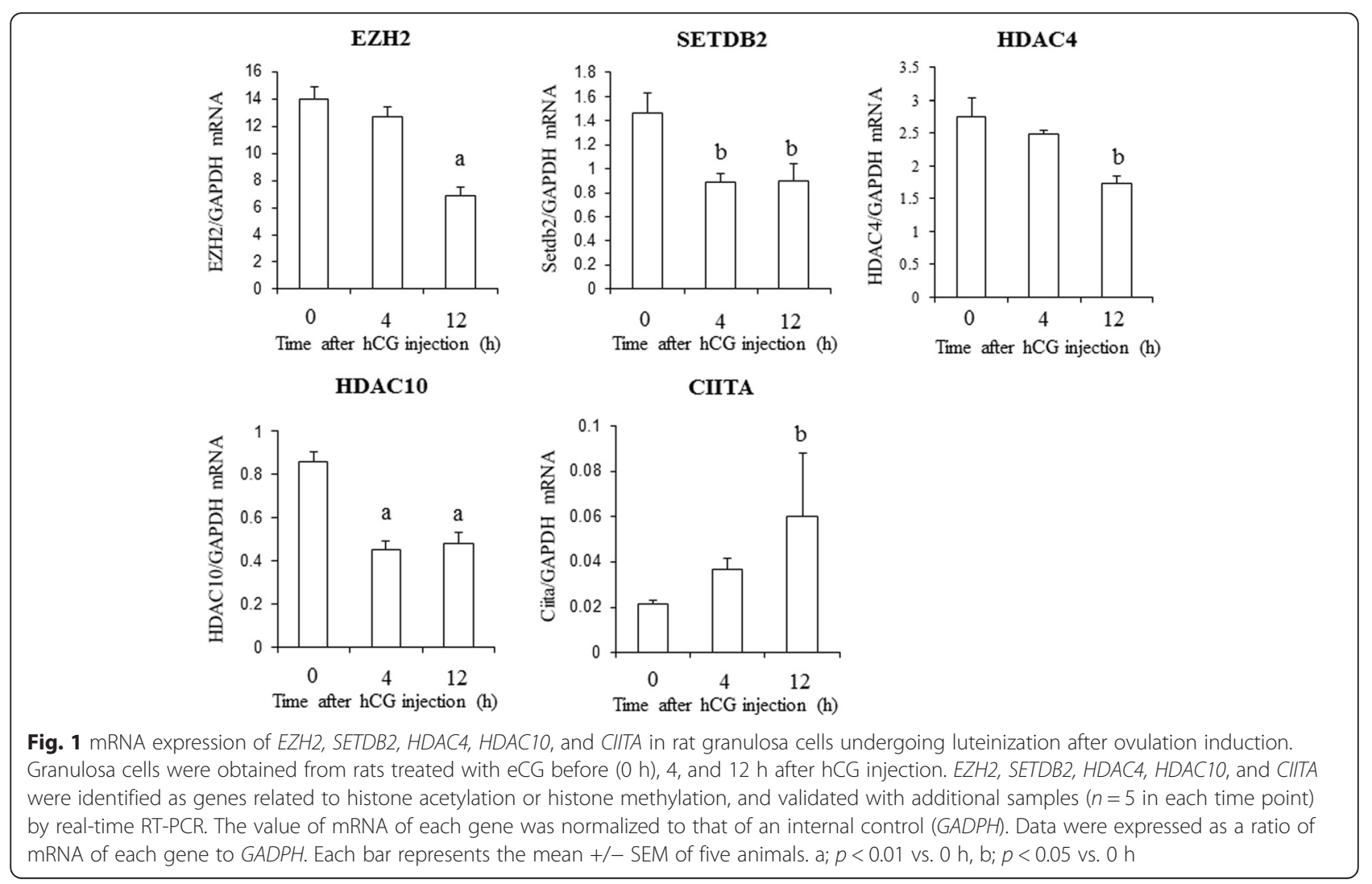


Since these two genes were not included in the PCR array used in this study, we examined them separately. The mRNA expression level of NCOA7 significantly increased $4 \mathrm{~h}$ after hCG injection, while the mRNA expression level of HP1BP3 significantly decreased $12 \mathrm{~h}$ after hCG injection (Fig. 2).

To investigate the changes in the recruitment of EZH2 to the promoter regions of StAR and cyp19a1 after ovulation induction, the binding activities of EZH2 to those promoters were examined using a ChIP assay (Fig. 3). The binding activity of EZH2 to the StAR promoter region decreased after hCG injection while the binding activity of EZH2 to the cyp19a1 promoter region increased after hCG injection.

We also investigated whether ERK-1/2 is involved in the regulation of the histone modification at the StAR promoter region and its mRNA expression in granulosa cells undergoing luteinization in vitro. StAR mRNA levels were significantly increased by hCG stimulation with the significant increase in H3K4me3 of the StAR promoter region (Fig. 4a and b). StAR mRNA expression was significantly inhibited by the ERK inhibitor (U0126) accompanied by the significant decrease in H3K4me3 (Fig. 4c and d), suggesting that hCG increases StAR gene expression through the ERK-1/2-mediated signaling which is also associated with histone modification (H3K4me3) of the promoter region.

\section{Discussion}

Previous studies have shown that more than 300 genes were up-regulated by more than 4-fold in granulosa cells during ovulation after the ovulatory LH surge [27, 40]. mRNA expression levels of some genes increase by several hundred or even a 1000 -fold during this short period. These dramatic changes in gene expression of luteinizing granulosa cells are not only regulated by the activation of several transcription factors, but also by histone modifications $[25,26]$. This study showed that the gene expression of histone modification enzymes was altered in granulosa cells undergoing luteinization during ovulation. Among the 84 genes in the PCR array, five (HDAC4, HDAC10, EZH2, SETDB2, and CIITA) were identified in granulosa cells as histone acetylationor histone methylation-related genes. In addition, two genes (NCOA7 and HP1BP3) were examined as histone modification-related genes that act downstream of the ERK-1/2 signal. HDAC4, HDAC10, EZH2, SETDB2 and HP1BP3 have transcriptional repression activities, and CIITA and NCOA7 have transcriptional activation activities. All the changes in those histone modification enzymes shown in this study seem to be associated with activating gene expressions. However, it is unclear whether the changes in mRNA expression of the histone modification enzymes are actually related with the promoter specific-histone modification and mRNA expression of the target gene. Further studies are needed to clarify the relationship among the changes in mRNA expression of the histone modification enzymes, the promoter specific-histone modification, and gene expression of the target genes. Although the detailed role and the target genes of the altered histone modification enzymes are unclear, our results suggest that the changes in mRNA expression of the histone modification enzymes play important roles in regulating the expression of various genes during the early stage of luteinization, which may be critical for the subsequent corpus luteum formation.

We recently reported that the H3K27me3 status of the promoter region decreased in the StAR gene in granulosa

\section{NCOA7}

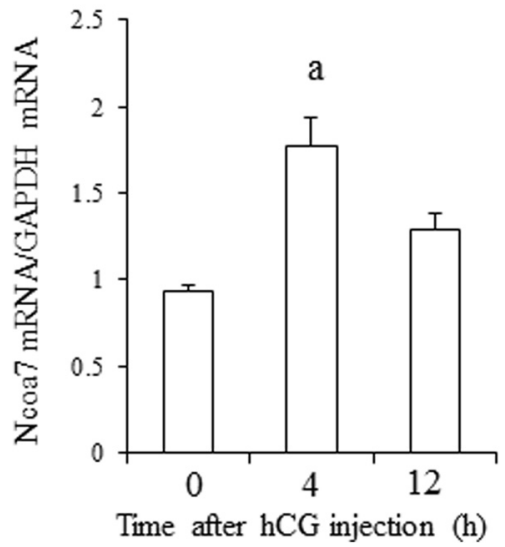

\section{HP1BP3}

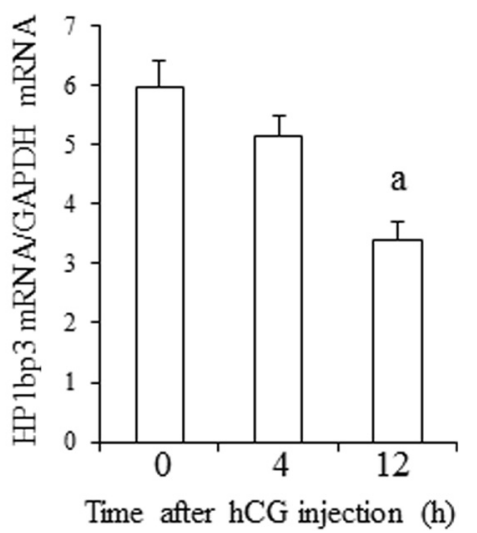

Fig. 2 mRNA expression of NCOA7 and HP1BP3 in granulosa cells undergoing luteinization after ovulation induction. NCOA7 and HP1BP3 are related to histone modification or chromatin remodeling and act downstream of the ERK1/2 signal after ovulation induction. mRNA expressions of both genes were analyzed in the same model as described in Figure 1. The value of mRNA of each gene was normalized to that of the internal control (GADPH). Each bar represents the mean $+/-$ SEM of five animals. a; $p<0.01$ vs. $0 \mathrm{~h}$ 
StAR promoter

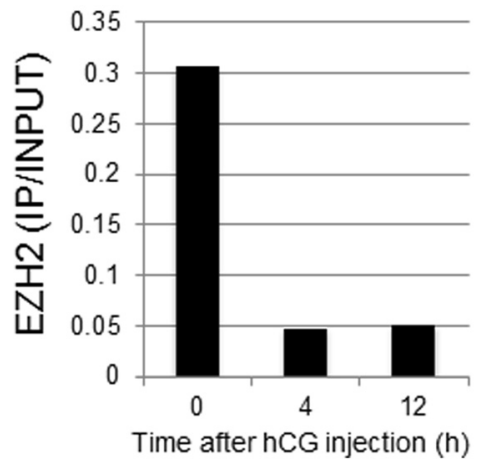

\section{cyp19a1 promoter}

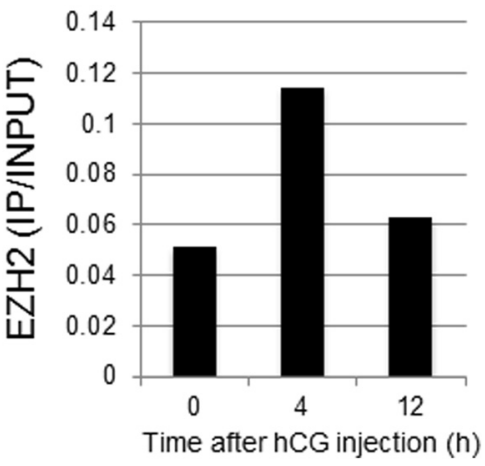

Fig. 3 Recruitment of EZH2 to the promoter regions of StAR and cyp19a1. Granulosa cells were obtained from three rats treated with eCG before ( $0 \mathrm{~h}$ ), 4 , and $12 \mathrm{~h}$ after $\mathrm{hCG}$ injection. Binding activities of EZH2 to the promoter region were analyzed by a ChIP assay. Each bar shows the IP/INPUT ratio. Data are representatives of four independent experiments
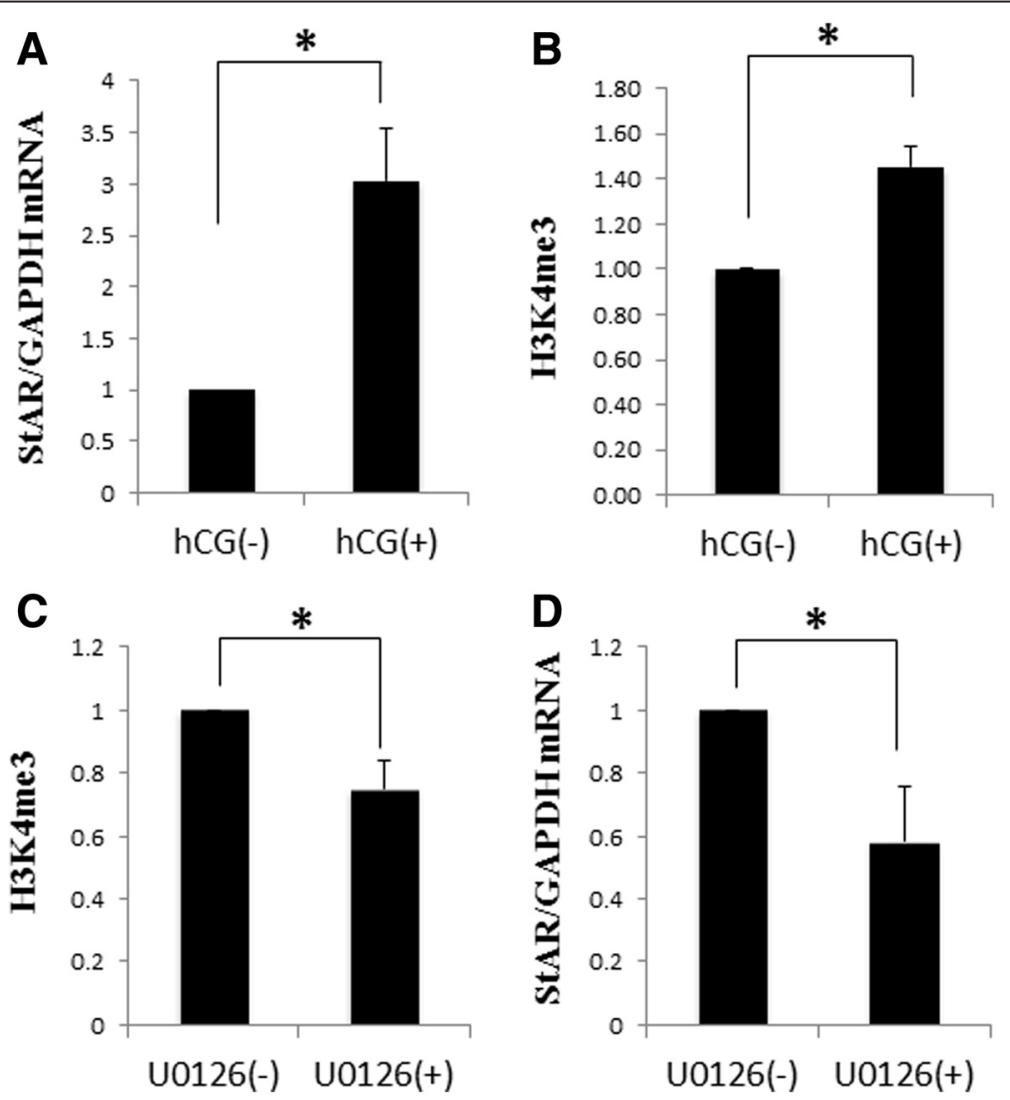

Fig. 4 Effects of the inhibitor of ERK-1/2 on H3K4me3 of the StAR promoter region and StAR mRNA expression in granulosa cells undergoing luteinization. Granulosa cells were isolated $48 \mathrm{~h}$ after eCG injection, and incubated with or without hCG for $4 \mathrm{~h}$ to induce luteinization (a, b). Granulosa cells were also incubated with or without the inhibitor of ERK (U0126, 10 M) for $2 \mathrm{~h}$ prior to hCG stimulation (c, d). StAR mRNA expression was measured by real-time RT-PCR. The value was normalized to an internal control (GADPH). Data were expressed as a percentage of the group without $h C G$. H3K4me3 of the StAR promoter region was analyzed by a ChIP assay. The IP/INPUT ratio was calculated and data were expressed as a percentage of the group without U0126. Each bar represents the mean +/- SEM of three independent experiments. *; $p<0.05$ vs. hCG (-) or U0126 (-) 
cells undergoing luteinization after ovulation induction while it increased in the cyp19a1 gene [25]. This change is consistent with the present result that the recruitment of $\mathrm{EZH} 2$, which induces H3K27me3, to the promoter region decreased in the StAR gene while it increased in the cyp19a1 gene after ovulation induction. In this study, mRNA levels of $E Z H 2$ decreased in granulosa cells undergoing luteinization after ovulation induction. The changes in mRNA expression of the histone modification enzymes are not always related with the promoter specific-histone modification of the target gene. mRNA levels of the histone modification enzymes are the total amount in the tissues, and do not reflect the local levels of the histone modification in the promoter region of the target gene. The recruitment of the histone modification enzymes to the promoter region is more closely related with the promoter specific-histone modification of the target gene.

Our results showed that ERK-1/2 signal is associated with an increase in $\mathrm{H} 3 \mathrm{~K} 4 \mathrm{me} 3$, which is an active mark of histone modifications, of the StAR promoter region in granulosa cells undergoing luteinization. Although a direct relationship between H3K4me3 of the StAR promoter and gene expression was not demonstrated in this study, our results support that hCG increases StAR gene expression through the ERK-1/2-mediated histone modification of the promoter region. Regarding how the promoter-specific histone modification is regulated or what kind of histone modification enzymes is preferentially recruited to the promoter region, further studies are needed.

The significant change in mRNA expression of DNA methylation-related genes such as DNMTs (DNMT1, $D N M T 3 a$, and DNMT3b) was not observed among the 84 genes in the PCR array in this study. However, we cannot ignore the possibility that DNA methylation is involved in regulating the expression of various genes in granulosa cells undergoing luteinization after ovulation induction, because the promoter specific-DNA methylation status can be altered even if the gene expression of DNA methylation enzymes did not change [41, 42]. In addition, DNA demethylation including TET should be taken into consideration for understanding the regulation of the DNA methylation [43, 44].

\section{Conclusions}

The present study showed that gene expressions of histone modification enzymes change in granulosa cells undergoing luteinization after ovulation induction. This suggests that histone modifications play important roles in regulating the expression of various genes during the early stage of luteinization, which may be critical for the subsequent corpus luteum formation.

\section{Abbreviations}

CBP: CREB-binding protein; DNMT: DNA methyltransferases; eCG: equine chorionic gonadotropin; ERK: extracellular regulated kinase; hCG: human chorionic gonadotropin; MHC: major histocompatibility complex.

\section{Competing interests}

The authors declare that they have no competing interests.

\section{Authors' contributions}

NS designed the study and LL collected the data. RM analyzed the data and drafted the first manuscript. MO, MS, IT and SS collected the data. HA and HT analyzed the data. NS directed the research and drafted the final manuscript. All authors approved the final manuscript.

\section{Acknowledgements}

R. Maekawa and L. Lee equally contributed to this work.

We thank Dr. Hiroshi Kimura, Tokyo Institute of Technology, for the gift of anti-H3K4me3 antibody.

This work was supported in part by JSPS KAKENHI Grants 24592471, 24791704, 24791705, 25293343, 25462559, 25462560, 25861495, 26670726, 26861328, 26861329, 26861330, and 26462492 for Scientific Research from the Ministry of Education, Science, and Culture, Japan.

Received: 7 December 2015 Accepted: 9 March 2016

Published online: 15 March 2016

\section{References}

1. Wissing ML, Kristensen SG, Andersen CY, Mikkelsen AL, Host T, Borup R, Grondahl ML. Identification of new ovulation-related genes in humans by comaring the transcriptome of granulosa cells before and after ovulation triggering in the same controlled ovarian stimulation cycle. Hum Reprod. 2014;29:997-1010.

2. Ronen-Fuhrmann T, Timberg R, King SR, Hales KH, Hales DB, Stocco DM, Orly J. Spatio-temporal expression patterns of steroidogenic acute regulatory protein (StAR) during follicular development in the rat ovary. Endocrinology. 1998;139:303-15.

3. Hickey GJ, Chen SA, Besman MJ, Shively JE, Hall PF, Gaddy-Kurten D, Richards JS. Hormonal regulation, tissue distribution, and content of aromatase cytochrome P450 messenger ribonucleic acid and enzyme in rat ovarian follicles and corpora lutea: relationship to estradiol biosynthesis. Endocrinology. 1988;122:1426-36.

4. Tanaka N, Espey LL, Kawano T, Okamura H. Comparison of inhibitory actions of indomethacin and epostane on ovulation in rats. Am J Physiol. 1991;260:E170-174.

5. Lydon JP, DeMayo FJ, Funk CR, Mani SK, Hughes AR, Montgomery Jr CA, Shyamala G, Conneely OM, O'Malley BW. Mice lacking progesterone receptor exhibit pleiotropic reproductive abnormalities. Genes Dev. 1995:9:2266-78.

6. Asada H, Yamagata Y, Taketani T, Matsuoka A, Tamura H, Hattori N, Ohgane J, Shiota K, Sugino N. Potential link between estrogen receptor-alpha gene hypomethylation and uterine fibroid formation. Mol Hum Reprod. 2008;14:539-45.

7. Maekawa R, Yagi S, Ohgane J, Yamagata Y, Asada H, Tamura I, Sugino N, Shiota K. Disease-dependent differently methylated regions (D-DMRs) of DNA are enriched on the X chromosome in uterine leiomyoma. J Reprod Dev. 2011;57:604-12.

8. Maekawa R, Sato S, Yamagata Y, Asada H, Tamura I, Lee L, Okada M, Tamura H, Takaki E, Nakai A, Sugino N. Genome-wide DNA methylation analysis reveals a potential mechanism for the pathogenesis and development of uterine leiomyomas. PLoS One. 2013;8:e66632.

9. Sato S, Maekawa R, Yamagata Y, Asada H, Tamura I, Lee L, Okada M, Tamura H, Sugino N. Potential mechanisms of aberrant DNA hypomethylation on the $x$ chromosome in uterine leiomyomas. J Reprod Dev. 2014;60:47-54.

10. Li B, Carey M, Workman JL. The role of chromatin during transcription. Cell. 2007;128:707-19.

11. Jaenisch R, Bird A. Epigenetic regulation of gene expression: how the genome integrates intrinsic and environmental signals. Nat Genet. 2003:33:245-54

12. Bird A. Perceptions of epigenetics. Nature. 2007:447:396-8.

13. Laird PW. Principles and challenges of genomewide DNA methylation analysis. Nat Rev Genet. 2010;11:191-203. 
14. Tamura I, Taketani T, Lee L, Kizuka F, Taniguchi K, Maekawa R, Asada H, Tamura H, Sugino N. Differential Effects of Progesterone on COX-2 and Mn-SOD Expressions Are Associated with Histone Acetylation Status of the Promoter Region in Human Endometrial Stromal Cells. J Clin Endocrinol Metab. 2011;96:E1073-1082.

15. Tamura I, Asada H, Maekawa R, Tanabe M, Lee L, Taketani T, Yamagata Y, Tamura H, Sugino N. Induction of IGFBP-1 expression by CAMP is associated with histone acetylation status of the promoter region in human endometrial stromal cells. Endocrinology. 2012;153:5612-21.

16. Tamura I, Sato S, Okada M, Tanabe M, Lee L, Maekawa R, Asada H, Yamagata Y, Tamura H, Sugino N. Importance of C/EBPbeta Binding and Histone Acetylation Status in the Promoter Regions for Induction of IGFBP-1, PRL, and Mn-SOD by CAMP in Human Endometrial Stromal Cells. Endocrinology. 2014;155:275-86.

17. Rada-Iglesias A, Bajpai R, Swigut T, Brugmann SA, Flynn RA, Wysocka J. A unique chromatin signature uncovers early developmental enhancers in humans. Nature. 2011;470:279-83.

18. Creyghton MP, Cheng AW, Welstead GG, Kooistra T, Carey BW, Steine EJ, Hanna J, Lodato MA, Frampton GM, Sharp PA, Boyer LA, Young RA, Jaenisch R. Histone H3K27ac separates active from poised enhancers and predicts developmental state. Proc Natl Acad Sci USA. 2010;107:21931-6.

19. Barski A, Cuddapah S, Cui K, Roh TY, Schones DE, Wang Z, Wei G, Chepelev I, Zhao K. High-resolution profiling of histone methylations in the human genome. Cell. 2007;129:823-37.

20. Zhang JA, Mortazavi A, Williams BA, Wold BJ, Rothenberg EV. Dynamic transformations of genome-wide epigenetic marking and transcriptional control establish T cell identity. Cell. 2012;149:467-82.

21. Tamura I, Ohkawa Y, Sato T, Suyama M, Jozaki K, Okada M, Lee L, Maekawa R, Asada H, Sato S, Yamagata Y, Tamura H, Sugino N. Genome-wide analysis of histone modifications in human endometrial stromal cells. Mol Endocrinol. 2014;28:1656-69.

22. Christenson LK, Stouffer RL, Strauss 3rd JF. Quantitative analysis of the hormone-induced hyperacetylation of histone $\mathrm{H} 3$ associated with the steroidogenic acute regulatory protein gene promoter. J Biol Chem. 2001;276:27392-9.

23. LaVoie HA. Epigenetic control of ovarian function: the emerging role of histone modifications. Mol Cell Endocrinol. 2005:243:12-8.

24. Martinez-Arguelles DB, Papadopoulos V. Epigenetic regulation of the expression of genes involved in steroid hormone biosynthesis and action. Steroids. 2010;75:467-76.

25. Lee L, Asada H, Kizuka F, Tamura I, Maekawa R, Taketani T, Sato S, Yamagata Y, Tamura H, Sugino N. Changes in histone modification and DNA methylation of the StAR and Cyp19a1 promoter regions in granulosa cells undergoing luteinization during ovulation in rats. Endocrinology. 2013;154:458-70.

26. Zhang YL, Xia Y, Yu C, Richards JA, Liu J, Fan HY. CBP-CITED4 is required for luteinizing hormone-triggered target gene expression during ovulation. Mol Hum Reprod. 2014;20:850-60.

27. Fan HY, Liu Z, Shimada M, Sterneck E, Johnson PF, Hedrick SM, Richards JS MAPK3/1 (ERK1/2) in ovarian granulosa cells are essential for female fertility. Science. 2009;324:938-41.

28. Tanabe M, Tamura H, Taketani T, Okada M, Lee L, Tamura I, Maekawa R, Aasada $H$, Yamagata $Y$, Sugino N. Melatonin protects the integrity of granulosa cells by reducing oxidative stress in nuclei, mitochondria, and plasma membranes in mice. J Reprod Dev. 2015;61:35-41.

29. Yamagata Y, Nishino K, Takaki E, Sato S, Maekawa R, Nakai A, Sugino N. Genome-wide DNA methylation profiling in cultured eutopic and ectopic endometrial stromal cells. PLoS One. 2014;9:e83612.

30. Cao R, Wang L, Wang H, Xia L, Erdjument-Bromage $H$, Tempst P, Jones RS, Zhang Y. Role of histone H3 lysine 27 methylation in polycomb-group silencing. Science. 2002;298:1039-43.

31. Czermin B, Melfi R, McCabe D, Seitz V, Imhof A, Pirrotta V. Drosophila enhancer of Zeste/ESC complexes have a histone $\mathrm{H} 3$ methyltransferase activity that marks chromosomal polycomb sites. Cell. 2002;111:185-96.

32. Falandry C, Fourel G, Galy V, Ristriani T, Horard B, Bensimon E, Salles G, Gilson E, Magdinier F. CLLD8/KMT1F is a lysine methyltransferase that is important for chromosomal segregation. J Biol Chem. 2010;285:20234-41.

33. Cheung WL, Briggs SD, Allis CD. Acetylation and chromosomal functions. Curr Opin Cell Biol. 2000;12:326-33.

34. Verdin E, Dequiedt F, Kasler HG. Class II histone deacetylases: versatile regulators. TRENDS in genetics. 2003;19:286-93.
35. Raval A, Howcroft TK, Weissman JD, Kirshner S, Zhu XS, Yokoyama K, Ting J, Singer DS. Transcriptional coactivator, CIITA, is an acetyltransferase that bypasses a promoter requirement for TAFii250. Mol Cell. 2001;7:105-15.

36. Shkolnik K, Ben-Dor S, Galiani D, Hourvitz A, Dekel N. Molecular characterization and bioinformatics analysis of Ncoa7B, a novel ovulationassociated and reproduction system-specific Ncoa7 isoform. Reproduction. 2008;135:321-33.

37. Shao W, Halachmi S, Brown M. ERAP140, a conserved tissue-specific nuclear receptor coactivator. Mol Cell Biol. 2002;22:3358-72.

38. Dutta B, Ren Y, Hao P, Sim KH, Cheow E, Adav S, Tam JP, Sze SK. Profiling of the chromatin-associated proteome identifies HP1BP3 as a novel regulator of cell cycle progression. Mol Cell Proteomics. 2014;13:2183-97.

39. Dutta B, Ren Y, Lim SK, Cheow E, Tam JP, Sze SK. Quantitative profiling of chromatome dynamics reveals a novel role for HP1BP3 in hypoxia-induced oncogenesis. Mol Cell Proteomics. 2014;13:3236-49.

40. Hernandez-Gonzalez I, Gonzalez-Robayna I, Shimada M, Wayne CM, Ochsner SA, White L, Richards JS. Gene expression profiles of cumulus cell oocyte complexes during ovulation reveal cumulus cells express neuronal and immune-related genes: does this expand their role in the ovulation process? Mol Endocrinol. 2006;20:1300-21.

41. Yamagata Y, Maekawa R, Asada H, Taketani T, Tamura I, Tamura H, Ohgane J, Hattori N, Shiota K, Sugino N. Aberrant DNA methylation status in human uterine leiomyoma. Mol Hum Reprod. 2009;15:259-67.

42. Maekawa R, Sato S, Okada M, Lee L, Tamura I, Jozaki K, Kajimura T, Asada H, Yamagata Y, Tamura H, Yamamoto S, Sugino N: Tissue-specific expression of estrogen receptor 1 is regulated by DNA methylation in a T-DMR. Mol Endocrinol. 2016. in press.

43. Zhu JQ, Zhu L, Liang XW, Xing FQ, Schatten H, Sun QY. Demethylation of LHR in dehydroepiandrosterone-induced mouse model of polycystic ovary syndrome. Mol Hum Reprod. 2010;16:260-6.

44. Wang P, Zhao H, Li T, Zhang W, Wu K, Li M, Bian Y, Liu H, Ning Y, Li G, Chen ZJ. Hypomethylation of the LH/choriogonadotropin receptor promoter region is a potential mechanism underlying susceptibility to polycystic ovary syndrome. Endocrinology. 2014;155:1445-52.

\section{Submit your next manuscript to BioMed Central and we will help you at every step:}

- We accept pre-submission inquiries

- Our selector tool helps you to find the most relevant journal

- We provide round the clock customer support

- Convenient online submission

- Thorough peer review

- Inclusion in PubMed and all major indexing services

- Maximum visibility for your research

Submit your manuscript at www.biomedcentral.com/submit 